\title{
Preserved xenogenic amniotic membrane as a patch on the repair of superficial corneal ulcers in rabitts
}

\author{
Kelly Cristine de Sousa Pontes ${ }^{1 *}$, Andréa Pacheco Batista Borges ${ }^{1}$, Renato Barros Eleotério ${ }^{2}$, \\ Emily Correna Carlo Reis ${ }^{1}$, Tatiana Schmitz Duarte ${ }^{1}$
}

\begin{abstract}
The aim of this study was to evaluate the effects of canine amniotic membrane, previously preserved in glycerin, used as a patch on the repair of experimentally-made superficial corneal ulcers and to compare corneal epithelization between the treated and non-treated groups. Xenogeneic amniotic membranes were collected aseptically and preserved in 99\% glycerin at room temperature. Each animal was anesthetized and submitted to superficial corneal keratectomy of the left eye. The treated group received a fragment of canine amniotic membrane as a patch, while the control group had no treatment. The treated group showed blepharospasm, ocular discharge and conjunctival congestion. The membrane accelerated corneal repair in the beginning of the process, however, it delayed its conclusion $(\mathrm{p}<0.05)$. Treated eyes showed greater vessel formation and decreased corneal transparency $(\mathrm{p}<0.05)$. The stroma of the control group was thicker than that of the treated group $(\mathrm{p}<0.05)$. We suggest that amniotic membrane used in this manner can be applied as a therapy for superficial corneal ulcers in the beginning phases of the repair process.
\end{abstract}

Key words: cornea, surgery, veterinary ophthalmology, biomaterials.

\section{RESUMO}

\section{Membrana amniótica xenógena preservada, como bandagem, na reparação de úlcera de córnea superficial em coelhos}

O presente estudo teve como objetivo avaliar os efeitos da membrana amniótica canina, preservada em glicerina, usada como bandagem na reparação de úlceras superficiais experimentais de córneas de coelhos e comparar o tempo de epitelização das córneas, entre os grupos tratado e controle. As membranas foram colhidas assepticamente e preservadas em glicerina 99\%, em temperatura ambiente. Cada animal foi anestesiado e submetido a ceratectomia superficial no olho esquerdo. O grupo tratado recebeu um fragmento de membrana amniótica, como bandagem, e o grupo controle não recebeu tratamento. $\mathrm{O}$ grupo tratado apresentou blefarospasmo, secreção ocular e congestão conjuntival. A membrana amniótica acelerou o início do processo de reparação da córnea, porém retardou sua conclusão. As córneas tratadas demonstraram formação vascular e perda da transparência. $\mathrm{O}$ estroma do grupo controle apresentou-se mais espesso do que o do grupo tratado. Sugere-se que a membrana amniótica, utilizada da forma descrita, deva ser aplicada como terapia em úlceras superficiais da córnea na fase inicial do processo de reparação.

Palavras-chave: córnea, cirurgia, oftalmologia veterinária, biomateriais.

Recebido para publicação em 05/04/2011 e aprovado em 11/04/2012

${ }^{1}$ Doctor of Veterinary Medicine, DSc. Departamento de Veterinária, Universidade Federal de Viçosa, Av. Peter Henry Rolphs, s/nº , 36570-000, Viçosa, Minas Gerais, Brazil. kellycpontes@yahoo.com.br (*author for correspondence), andrea@ufv.br, bolsista do CNPq, emilycarlo@yahoo.com.br, tatianaduarte@ufv.br

${ }^{2}$ Doctor of Veterinary Medicine, MSc. Departamento de Veterinária, Universidade Federal de Viçosa, Av. Peter Henry Rolphs, s/nº, 36570-000, Viçosa, Minas Gerais, Brazil. renato_ufv@hotmail.com 


\section{INTRODUCTION}

Corneal ulcers feature among the most common ocular diseases in dogs and cats and ulcerative keratitis is one of these that have the highest rates of treatment success (Whitley, 1991). However, it can become complicated when the repair process is inhibited, when the cause has not been eliminated or the lesion becomes infected (Kern, 1990). Persistent ulcerative keratitis, which does not respond to clinical treatment, requires surgical treatment. The main goals - when surgery is applied - are corneal repair, preventing the ulcer's progression, protecting corneal surface and avoiding stromal degeneration (Portnoy et al., 1989).

Biological membranes have been used in reconstructive ophthalmologic surgeries. Reports on good results can be found using autogenic, allogeneic and xenogeneic membranes on the repair of ocular surfaces after traumas. Among these, amniotic membrane has shown great results (Cremonini et al., 2007; Kim et al., 2009; Pontes et al., 2010).

The amniotic membrane's epithelium has especial functions; for instance, anti-adhesive effect, bacteriostatic properties, lesion protection and effect on the epithelization process. It is also responsible for diminishing pain and lacks antigenicity even when allogeneic and fresh (Azuara-Blanco, 1999).

Amniotic membranes can be used in two ways in ophthalmologic surgeries. As a graft, the membrane is used as a scaffold for cell migration, becoming epithelized and then incorporated to the host tissue. For this, it should be positioned with its epithelium facing the outside. As a patch, the membrane is used in order to restrain inflammatory reaction while epithelization occurs under it, and so, the membrane epithelium must be positioned facing the wound surface (Dua et al., 2004).

In this research, clinical and histomorphometric analysis were used to study the effects of canine amniotic membrane previously preserved in glycerin at room temperature, used as a patch on the repair of experimentally-made superficial corneal ulcers in rabbits. We also compared the period of time needed for corneal epithelization in animals treated with the membrane and those that have not been treated with it and evaluated the period of time needed to complete corneal transparency reestablishment and the occurrence of incorporation of the membrane by the host corneal tissue.

\section{MATERIALS AND METHODS}

The experiments were previously approved by the DVT/UFV Ethic Committee, protocol number 85/2006, in agreement with bioethical criteria followed by the Association for Research in Vision and Ophthalmology (ARVO) and the National Institutes of Health Publications
No 85-23: Revised 1985, in the light of the Nüremberg code (Goldim, 1995)

The preparation of the canine amniotic membrane followed guidelines from the literature (Pontes et al., 2010; Barros et al., 1998; Kim \& Tseng, 1995), being aseptically collected from a healthy pregnant female dog carrying nearly-born fetuses. The membrane was separated from the chorion, cleaned with $0.9 \%$ sterile saline solution ${ }^{3}$ at room temperature and stretched on a nitrocellulose paper with its epithelial surface facing up. It was then immersed in a phosphate buffer solution containing $1000 \mathrm{UI} / \mathrm{mL}$ of penicillin $\mathrm{G}, 20 \mu \mathrm{g} / \mathrm{mL}$ of streptomycin and $2.5 \mu \mathrm{g} / \mathrm{ml}$ of amphotericin $B^{4}$. Finally, it was immersed on $99 \%$ glycerin $^{5}$ and kept at room temperature for 30 days, for latter surgical use and microbiological analysis.

Twenty-eight healthy adult New Zealand white rabbits, weighting 3.0 to $4.0 \mathrm{~kg}$, were randomly divided into two equal groups of 14 animals each. The rabbits in the treated group (TG) received the xenogeneic amniotic membrane and the animals in the control group (CG) remained untreated. All animals were kept in individual cages and fed commercial food and water. The 14 animals of the TG were randomly divided into six subgroups of 2 animals each, to collect the corneas. The collections took place on the $1^{\text {st }}, 2^{\text {nd }}, 7^{\text {th }}, 15^{\text {th }}, 30^{\text {th }}, 60^{\text {th }}$ and $180^{\text {th }}$ day after the surgery. The 14 animals of the CG were randomly divided into six subgroups, of 2 animals each, to collect the corneas on the $1^{\text {st }}, 2^{\text {nd }}, 7^{\text {th }}, 15^{\text {th }}, 30^{\text {th }}, 60^{\text {th }}$ and $180^{\text {th }}$ day after the surgery.

Animals were sedated with acepromazine ${ }^{6}(0.1 \mathrm{mg} / \mathrm{kg}$, IV) and 15 minutes later were anesthetized with tiletamine and zolazepam ${ }^{7}(30 \mathrm{mg} / \mathrm{kg}$, IM).

They were positioned on right lateral decumbent so the cornea was positioned parallel to the table, the periocular area was shaved and aseptically cleaned with a $10 \%$ povidone-iodine solution.

On a sequence, the cornea, palpebral and bulbar conjunctivas were rinsed with a $0.5 \%$ povidone-iodine solution, followed by $0.9 \%$ sterile saline solution. The eyeball was immobilized by two supporting sutures using a 3-0 nylon ${ }^{8}$ with needle at 6 o'clock and 12 o'clock positions trespassing the bulbar conjunctiva at a distance of $0.5 \mathrm{~cm}$ from the limb. For the eyeball fixation, a Barraquer ocular speculum was used. The surgeries were made under a surgical microscope ${ }^{9}$.

Superficial keratectomy was made on the left eye of each animal in both groups using a $5 \mathrm{~mm}$-diameter

\footnotetext{
${ }^{3}$ JP Indústria Farmacêutica Ltda., São Paulo, Brazil.

${ }^{4}$ Ophthalmos Pharmaceutical Industry Ltda., São Paulo, Brazil.

${ }^{5}$ Glycerin, P.A., Isofar Industry and Trade in Chemicals Ltda., Rio de Janeiro, Brazil.

${ }^{6}$ Vetnil Indústria e Comércio de Produtos Veterinários Ltda., São Paulo, Brazil.

${ }^{7}$ Virbac do Brasil, São Paulo, Brazil.

${ }^{8}$ Ethicon®, Johnson \& Johnson, São Paulo, Brazil.

${ }^{9}$ DF - Vasconcelos, MCT model, line: MC-M222, São Paulo, Brazil.
} 
Castroviejo trephine at 2 o'clock position, $3 \mathrm{~mm}$ from the limbus. The resulting corneal fragment of $5.0 \mathrm{~mm}$ in diameter and $0.15 \mathrm{~mm}$ tick was then excised. The operated eye received anesthetic drops of $4.0 \%$ lidocaine, at regular 20 minute-intervals during the procedure.

In the treated group, a fragment of amniotic membrane, previously rehydrated for 10 minutes in sterile saline solution was positioned on the defect, with its epithelial surface facing the cornea. The membrane was sutured to the cornea with separate $9-0$ monofilament nylon ${ }^{10}$ sutures using a needle. The sutures crossed completely the membrane but not the host cornea.

Post-surgery care included drops of $0.175 \%$ neomycin, $10.000 \mathrm{UI} / \mathrm{mL}$ of polymyxin B and $400 \mathrm{UI}$ of bacitracin (1 drop, 6 hour-interval for 7 days). Analgesia also included morphine ${ }^{11}(0.3 \mathrm{mg} / \mathrm{kg}$, subcutaneously in a 6 hour-interval for 3 days). All animals were kept in individual cages using Elizabethan collars until complete corneal epithelization.

Sutures removal occurred on the $7^{\text {th }}$ day after surgery; for this, animals were sedated using acepromazine ${ }^{12}$ $(0.1 \mathrm{mg} / \mathrm{kg}, \mathrm{IV})$ followed by corneal anesthesia with $4.0 \%$ lidocaine drops.

Blepharospasm, ocular discharge, conjunctival vascular congestion, corneal vascularization and the presence of the membrane were clinically evaluated and classified as present or absent, by direct illumination and slit lamp biomicroscopy ${ }^{13}$. Daily examinations started 24 hours after surgery, on the first 7 days, then on 48 hoursintervals for another 7 days and then on 96 hours-intervals until 180 days after surgery. Fluorescein coloring test was daily applied, beginning 48 hours after surgery and classified as positive or negative.

Cornea and implant opacity were classified as absent, discrete when in nebula and severe, when in leukoma.

The two animals of each subgroup were submitted to euthanasia on 1,2, 7, 15, 30, 60 and 180 days after surgery, using first sedation with acepromazine $(0,1 \mathrm{mg} / \mathrm{kg} / \mathrm{IV})$. After fifteen minutes, they received sodium thiopental ${ }^{14}$ through the same pathway in a dose sufficient to cause respiratory and cardiac failure. Only then, $5 \mathrm{~mL}$ of intravenous potassium chloride ${ }^{15}$ was administered.

The operated eye was then enucleated and fixed in Bouin solution. After a 24 hour fixation period, the samples were immersed in $70 \%$ alcohol solution and cut longitudinally in such way that the cornea was privileged. After dehydration and diaphanization, the samples were then infiltrated in paraffin. Sections $4 \mu \mathrm{m}$ thick were

\footnotetext{
${ }^{10}$ Micro Nylon®, Microsuture, São Paulo, Brazil.

"Dimorf®, Cristália Pharmaceutical Products, São Paulo, Brazil.

${ }^{12}$ Acepran $\circledast$, Univet, São Paulo, Brazil.

${ }^{13}$ SL-15 Portable Slit Lamp®, Kowa, Tokyo, Japan.

${ }^{14}$ Thiopentax®, Cristália Produtos Químicos Farmacêuticos, São Paulo,

Brazil.

${ }^{15}$ Isofarma, Ceará, Brazil.
}

obtained with a rotary microtome and stained with either hematoxylin-eosin (HE) or Gomori trichrome (GT).

Histological and histomorphometric studies were carried out with a light microscope to evaluate corneal epithelization, the membrane incorporation to the cornea, edema and presence of leukocytes, fibroblasts proliferation and thickness of epithelium and stroma. Corneal epithelization and membrane incorporation were classified as absent, complete or incomplete; corneal edema as present or absent and other variables according to histomorphometric results (Aherne \& Dunnill, 1982).

Variables were submitted to Wilcoxon non-parametric test, considering a significance level of $p<0.05$. Dichotomic variables were compared in contingence tables and analyzed using chi-squared test, also $p<0.05$ (Sampaio, 2002).

\section{RESULTS}

Blepharospasm was present until the $2^{\text {nd }}$ day in three animals of the control group (CG) and until the $9^{\text {th }}$ day in twelve animals of the treated group. Statistical analysis showed that it was significantly greater $(p<0.05)$ in animals of the treated group (TG) until the $9^{\text {th }}$ day after surgery. From the $10^{\text {th }}$ day forward, no significant difference $(p<0.05)$ between groups was found, being absent in all animals (Figure 1).

Ocular discharge was seen until the $2^{\text {nd }}$ day after surgery in five animals of the CG and until the $13^{\text {th }}$ day in all animals of the TG. Statistically, it was greater $(p<0.05)$ in TG animals but, from the $14^{\text {th }}$ day on, this difference was not observed between the groups, being absent in all animals (Figure 2). Conjunctival vascular congestion was present until the $3^{\text {th }}$ day in ten animals of the CG and for 15 days in all animals of the TG. Statistically, it was greater $(p<0.05)$ in TG animals until the $15^{\text {th }}$ day after surgery. From the $16^{\text {th }}$ day, it was not significant $(p<0.05)$ between groups because, after days 4 and 15 after surgery, it was absent in the control and the treated groups, respectively (Figure 3).

For the clinical identification of the epithelization, fluorescein staining showed positive results for longer time in animals of the treated group than in the control group. In the TG, positive tests were recorded during 23 days after surgery in one animal, 24 days in another and 26 days in a third one. In the CG, the fluoresecin test was positive only for one animal, lasting for 12 days. Other animals in the CG showed negative results before 12 days. No significant difference was found in the first 8 days after surgery. From the $9^{\text {th }}$ to the $23^{\text {rd }}$ day after surgery, there was significant difference $(p<0.05)$ between groups and, from the $24^{\text {th }}$ day on, there was not any significant difference $(p<0.05)$ (Fig.4). 


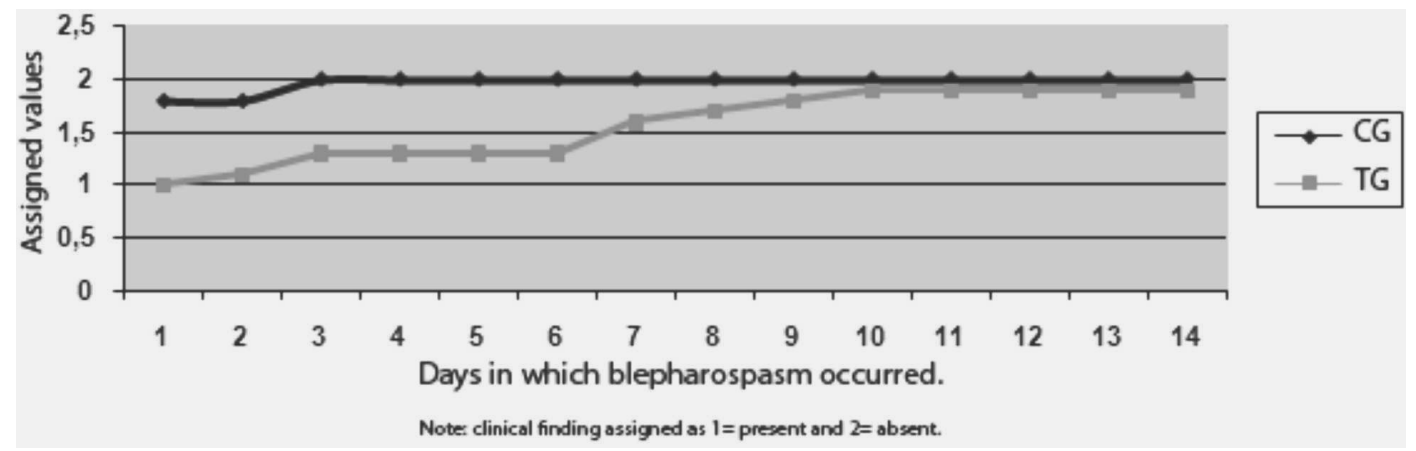

Figure 1. Graphical representation of mean values attributed to blepharospasm in rabbits treated with the amniotic membrane (TG) and control group (CG), after experimental superficial keratectomy.

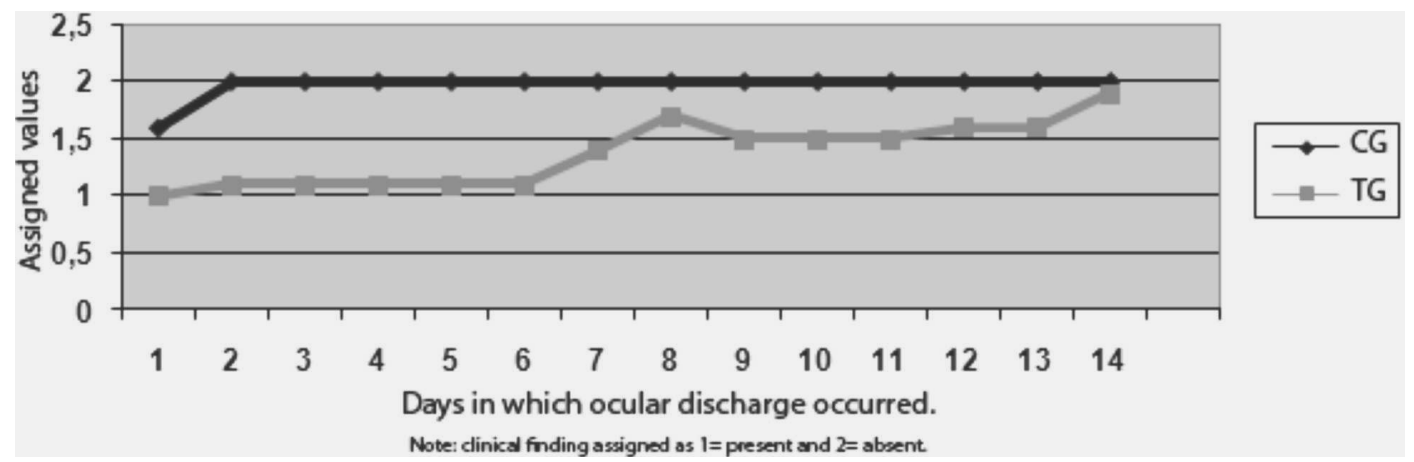

Figure 2. Graphical representation of mean values attributed to ocular dicharge in rabbits treated with the amniotic membrane (TG) and control group (CG), after experimental superficial keratectomy.

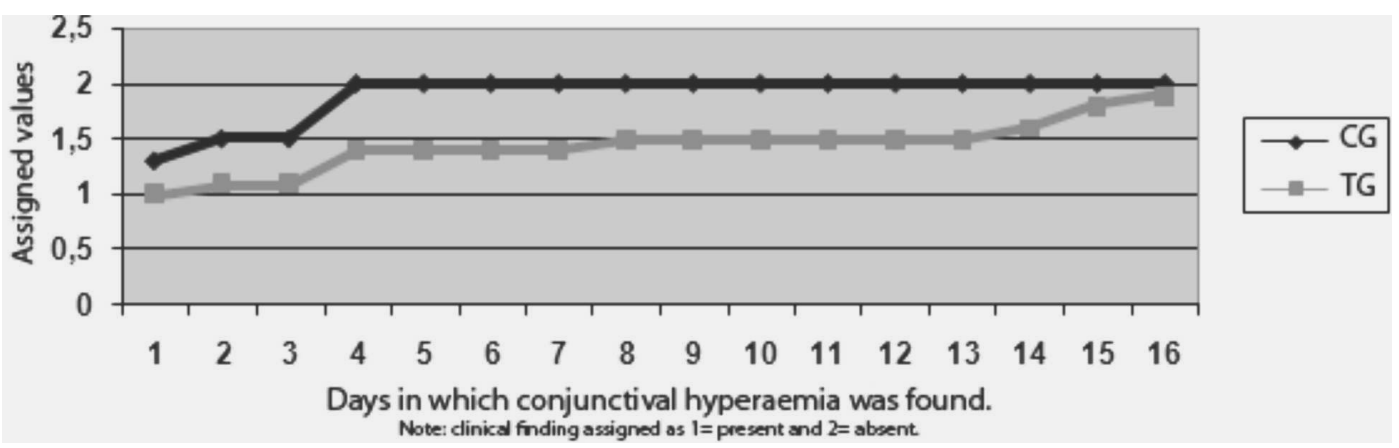

Figure 3. Graphical representation of mean values attributed to conjunctival hyperaemia in rabbits treated with the amniotic membrane (TG) and control group (CG), after experimental superficial keratectomy.

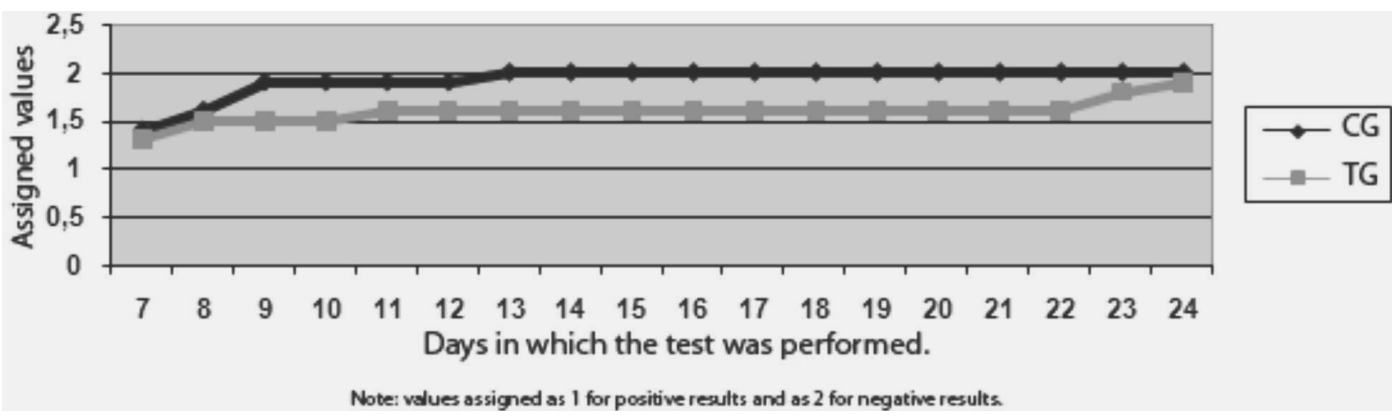

Figure 4. Graphical representation of mean values attributed to fluorescein coloring test in rabbits treated with the amniotic membrane (TG) and control group (CG), after experimental superficial keratectomy.

Rev. Ceres, Viçosa, v. 59, n.3, p. 313-320, mai/jun, 2012 


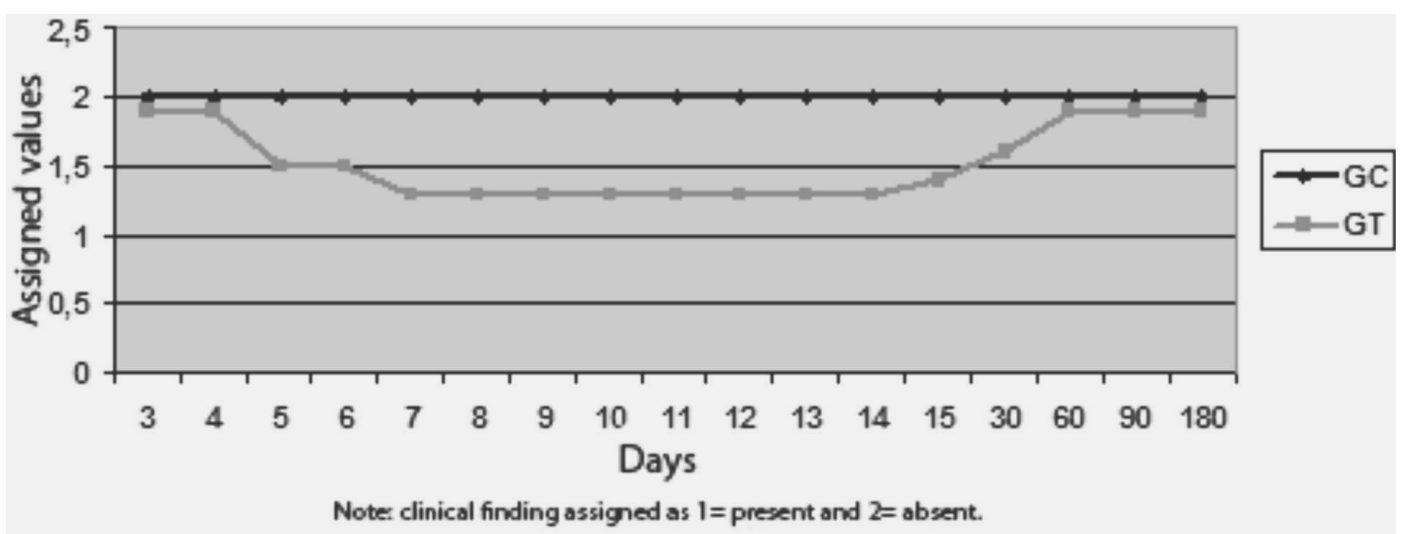

Figure 5. Graphical representation of mean values attributed to corneal vascularization in rabbits treated with the amniotic membrane (TG) and control group (CG), after experimental superficial keratectomy.

Corneal vascularization was clinically visualized from the $4^{\text {th }}$ day after surgery and persisted for 54 days in TG. In the CG, it did not occur. Statistically, there was no significant difference $(p<0.05)$ between the groups until the $4^{\text {th }}$ day after surgery. Between days 5 and 30 after surgery, there was significant difference $(p<0.05)$. From the $30^{\text {th }}$ day, no significant difference $(p<0.05)$ was found between groups (Fig.5), with the regression of vessels in TG.

The clinical evaluation of the control group showed that there was no corneal opacity from day 4 to day 13 after surgery. From then, nebula occurred, persisting for the rest of the observation period. The corneas that received amniotic membrane showed nebula from the first day after the procedure, remaining with such intensity for 15 days the most. Leucoma occurred in 7 animals in this group, showing regression to nebula in 6 of these animals (figure 6).

Histology showed that amniotic membrane was not incorporated to the host corneas. Epithelization began on the second day in TG while in control animals it started only on the $7^{\text {th }}$ day. However, epithelization was still incomplete on days 7 and 15 in treated animals, while in control ones it was almost complete.

The number of neutrophils invading corneal stroma of the animals in CG was greater than in TG (Table 1). These cells weren't found in areas of the cornea without lesion in both groups. In the TG, these cells were found only surrounding the sutures and in great number associated to the membranes (Figures 7 and 8).

The number of fibroblasts was greater in TG animals (Table 2). Their proliferation was seen in one animal on day 7 and in six animals on days 15, 30 and 60 after surgery. In the CG, these cells were seen in four animals at 15 and 30 days and in one animal at 60 days after surgery (Figure 9).

In both group, corneal edema was seen in all animals only in the first and second days after surgery. In these animals, corneal epithelization was not detected by histology.

Histomorphometric evaluation of corneal thickness of TG animals showed no significant difference $(\mathrm{p}<0,05)$ between normal and wounded stroma (Tables 3 and 4). The mean value of normal corneal stroma was $457.5 \mu \mathrm{m}$ and of wounded stroma was $470 \mu \mathrm{m}$. The control group presented significant difference between normal and wounded areas of the stroma, but not between the same areas of the epithelium $(\mathrm{p}<0,05)$. The means of normal corneal stroma in this group was $285.7 \mu \mathrm{m}$ and in wounded area was $300.0 \mu \mathrm{m}$. In normal corneal epithelium the mean was $30.0 \mu \mathrm{m}$ and in wounded area of epithelium was $29,0 \mu \mathrm{m}$.

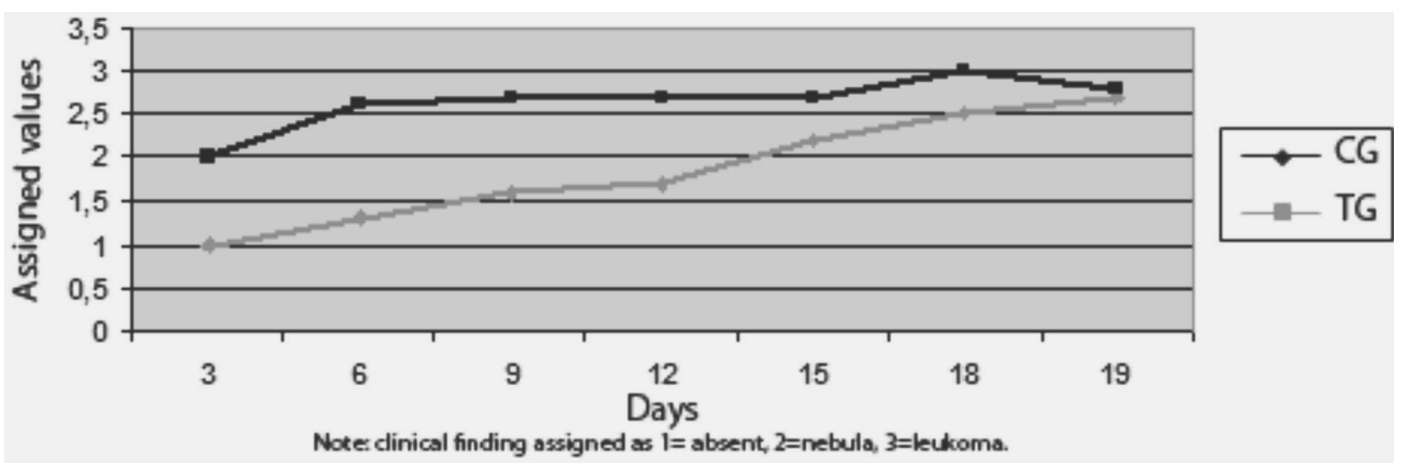

Figure 6. Graphical representation of mean values attributed to corneal opacity in rabbits treated with the amniotic membrane (TG) and control group (CG), after experimental superficial keratectomy. 


\section{DISCUSSION}

It is accepted that the sutures were responsible for blepharospasm as its resolution occurred after the sutures' removal on the $7^{\text {th }}$ day after surgery (Barros et al., 1998). Additionally, blepharospasm lasted longer in TG animals because of the delayed wound healing in this group.

It is known that amniotic membrane is not antigenic when used as a homologous transplant (Trelford \& Trelford-Sauder, 1979). Inflammatory inhibitors are present on epithelium cells of fresh amniotic membrane (Hao et al., 2000). Therefore, the occurrence of mucous ocular discharge and persistent conjunctival congestion in TG animals suggest a response to the amniotic membrane, as it was xenogeneic and preserved in $99 \%$ glycerin.

Ocular discharge in CG animals occurred as expected in a corneal ulcerative process as a response to the stimulus of globet cells (Kern, 1990). Although less intense in these animals, conjunctival vessels congestion occurred due to the trauma caused by supporting sutures applied during surgery to immobilize the eye ball. In TG, congestion occurred due to the same reason, but its persistence until the $15^{\text {th }}$ day after surgery was a result of inflammatory reaction and the delayed corneal repair process.

Table 1. Results, over 180 days, from the chi-squared test for polymorphonucleated present in the stroma wounded area from the animals treated with amniotic membrane (TG) and control (CG) after experimental superficial keratectomy and quantification by histomorphometry

\begin{tabular}{lcccccc}
\hline \multirow{2}{*}{ Groups } & \multicolumn{2}{c}{ Points with PMC* } & & \multicolumn{2}{c}{ Points without PMC } & \multirow{2}{*}{ Total NCP** } \\
\cline { 2 - 3 } & Total & $\%$ & & Total & $\%$ & 4200 \\
\hline CG & $54^{\mathrm{a}}$ & 1.3 & & $4146^{\mathrm{a}}$ & 98.7 & 4200 \\
TG & $0^{\mathrm{b}}$ & 0.0 & & $4200^{\mathrm{b}}$ & 100.0 & \\
\hline
\end{tabular}

Note: different letters in the same column indicate a significant difference at $5 \%$ of probability level. TG: group treated with amniotic membrane patch; CG: clinical treatment.

* PMC - Polymorphonucleated cells.

** NCP - Total number of counted points.

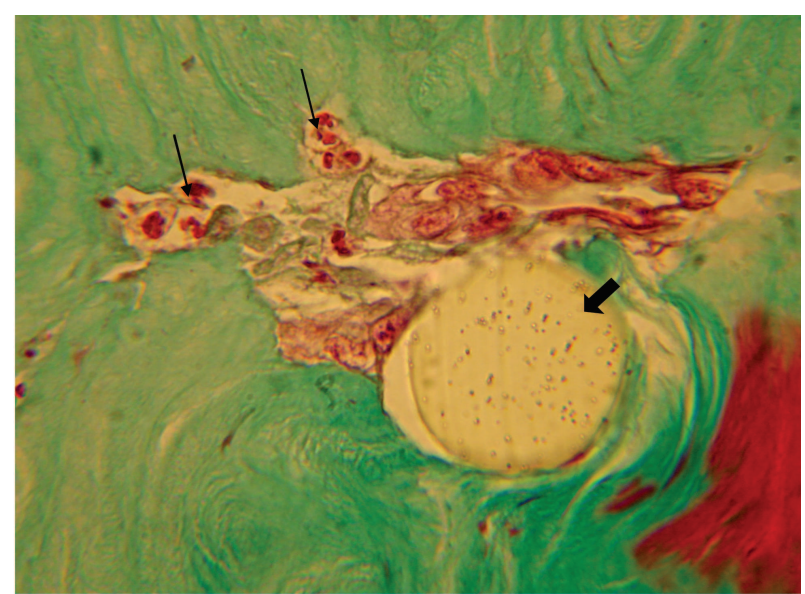

Figure 7. Photomicrograph of rabbit corneal stroma of the treated group 24 hour after superficial keratectomy and treatment with canine preserved amniotic membrane. Note the presence of polymorphonuclear cells (thin arrows) around suture (large arrouw). (1000x - GT).

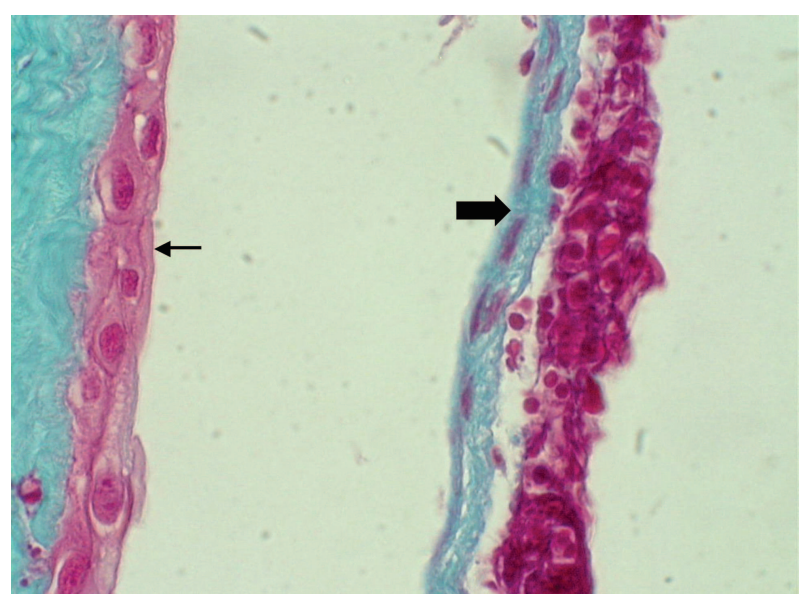

Figure 8. Photomicrograph of rabbit corneal treated epitelium (thin arrows) and amniotic membrane (large arrow). Note the inflammatory cells on amniotic membrane. (1000x - GT).

Table 2. Results, over 180 days, from the chi-squared test for fibroblasts present in the stroma wounded area from the animals treated with the amniotic membrane (TG) and control (CG) after experimental superficial keratectomy and quantification by histomorphometry

\begin{tabular}{|c|c|c|c|c|c|}
\hline \multirow{2}{*}{ Groups } & \multicolumn{2}{|c|}{ PCF* } & \multicolumn{2}{|c|}{ PWF** } & \multirow{2}{*}{$\mathbf{N C P}^{* * * *}$} \\
\hline & Total & $\%$ & Total & $\%$ & \\
\hline $\mathrm{GC}$ & $615^{a}$ & 14.6 & $3585^{\mathrm{a}}$ & 85.4 & 4200 \\
\hline GT & $1012^{\mathrm{b}}$ & 24.1 & $3188^{\mathrm{b}}$ & 75.9 & 4200 \\
\hline
\end{tabular}

Note: different letters in the same column indicate a significant difference at $5 \%$ of probability level. TG: group treated with amniotic membrane patch; CG: clinical treatment.

* PCF - Points containing fibroblasts

** PWF - Points without fibroblasts.

*** NCP - Total number of counted points. 


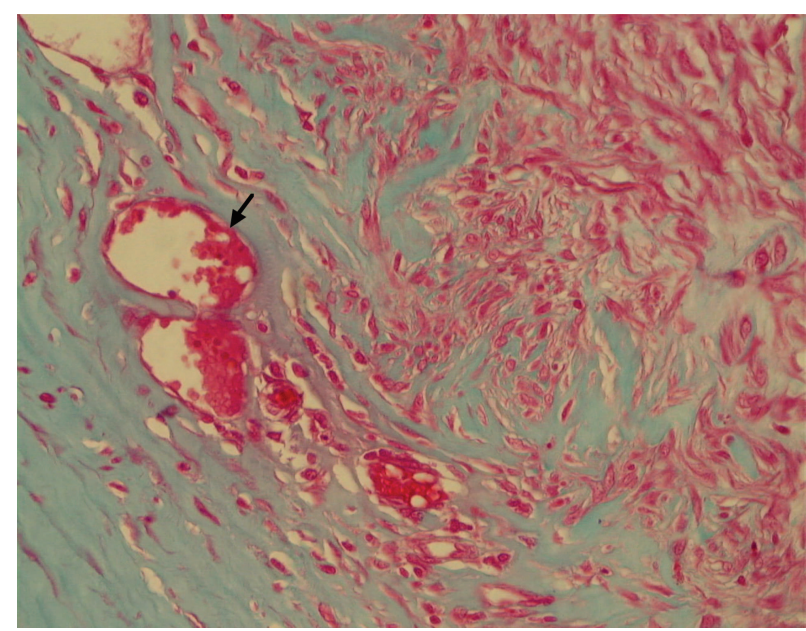

Figure 9. Photomicrograph of rabbit corneal stroma of the treated group 30 days after superficial keratectomy and treatment with canine preserved amniotic membrane. Note the presence of fibroblasts and vascularization (arrow). (GT - 400x).

Table 3 - Mean values ( $\mu \mathrm{m})$ of corneal stomal and epithelium thicknesses of rabbits treated with the amniotic membrane (TG) after experimental superficial keratectomy and measurements by histomorphometry, over 180 days

\begin{tabular}{lcc}
\hline & Stroma $(\boldsymbol{\mu m})$ & Epithelium $(\boldsymbol{\mu m})$ \\
\hline Normal area & $457.5^{\mathrm{a}}$ & $42.3^{\mathrm{a}}$ \\
Wounded area & $470.0^{\mathrm{a}}$ & $41.0^{\mathrm{a}}$ \\
\hline
\end{tabular}

Note: same letters in the same column indicate no significant difference by the Wilcoxon test at $5 \%$ of probability level. TG: group treated with amniotic membrane patch.

Table 4 - Mean values $(\mu \mathrm{m})$ of corneal stomal and epithelium thicknesses of rabbits in control group (CG) after experimental superficial keratectomy and measurements by histomorphometry, over 180 days

\begin{tabular}{lcc}
\hline & Stroma $(\boldsymbol{\mu m})$ & Epithelium $(\boldsymbol{\mu m})$ \\
\hline Normal area & $285.7^{\mathrm{a}}$ & $30.0^{\mathrm{a}}$ \\
Wounded area & $300.0^{\mathrm{b}}$ & $29.0^{\mathrm{a}}$ \\
\hline
\end{tabular}

Note: different letters in the same column indicate a significant difference by the Wilcoxon test at $5 \%$ of probability level. CG: clinical treatment.

The non incorporation of amniotic membrane to the host corneas confirms that the membrane's epithelium promotes wound protection and has an anti-adhesive effect, also reported by other authors when the membranes were used as a patch (Azuara-Blanco, 1999).

Histology results confirm clinical ones. Fluorescein staining indicated that the implant delayed the epithelization development. Similar observations were reported when comparing fresh with glycerin preserved amniotic membranes (Sampaio et al., 2006). Authors reported that amniotic membrane, preserved in $-80^{\circ} \mathrm{C}$ acted sequestrating lymphocytes and blocking their entrance in corneal stroma (Shimura et al., 2001).
In TG animals, the amniotic membrane acted restraining inflammatory cells on its surface and had an important role in wound protection, acting as a bandage; control corneas were invaded by inflammatory cells. It is possible that interleukins from lachrymal film and inflammatory cells did not bind to keratinocytes in stroma of TG animals in the same intensity as they did to these cells in CG animals. It is suggested that, as a result, keratinocytes in treated corneas underwent apoptosis in less intensity. The remaining keratinocytes started to proliferate and migrate, beginning an earlier corneal repair (Cassatella, 1995; Wilson et al., 2001).

Vascularization results indicate that amniotic membrane previously preserved in $99 \%$ glycerin at room temperature may have lost its anti-angiogenic properties. Additionally, the delayed epithelial repair may have contributed to the chronic signs in TG animals. In the CG, the repair process occurred faster and no vascularization was observed.

Corneal opacity can be attributed to the presence of the amniotic membrane, the delayed repair process and the stimulus to vessel growth in the cornea. Vascularization allowed the deposition of granulation tissue and the formation of a scar; this last one was more dense and opaque in the treated corneas. In the CG, it occurred without vascular formation (Slatter \& Dietrich, 2007). The animals were observed up to 180 days after surgery for corneal opacity evaluation.

The hydrophilic character of stromal collagen and mucopolysaccharides influence water entrance in the cornea while the epithelium acts as a barrier (Slatter \& Dietrich, 2007). In the present study, edema occurred only in animals in which epithelial repair was absent. The results reveal no differences between groups.

Edema and invasion of inflammatory cells give rise to an increase in stroma thickness (Spencer, 1996); which explains a greater mean value for stromal thickness of the wounded area in CG animals. The treated group did not show a significant inflammatory cells invasion except around the sutures.

\section{CONCLUSION}

Based on these results and according to the criteria of this research, it can be concluded that amniotic membrane preserved in $99 \%$ glycerin and used as a patch was beneficial in the initiation of tissue repair, accelerating the beginning of the process, protecting the cornea and restraining polymorphonucleated cells. Nevertheless, it delayed its later phases. Therefore, we suggest that the amniotic membrane used in these conditions can be applied as a therapy for superficial corneal ulcers in the initial phases of repair process. 


\section{ACKNOWLEDGMENTS}

Thanks to FAPEMIG, CNPq, CAPES, Ophthalmos Farmaceutic Industry Ltda and to Petrovich Surgical Instruments Ltda for material support.

\section{REFERENCES}

Aherne WA \& Dunnill MS (1982) Morphometry. Londres, Arnold. 205 p.

Azuara-Blanco A, Pillai CT \& Dua HS (1999) Amniotic membrane transplantation for ocular surface reconstruction. Brasilian Journal of Ophthalmology, 83:399-402.

Barros PSM, Garcia JA \& Laus JL (1998) The use of xenologous amniotic membrane to repair canine corneal perforation created by penetrating keratectomy. Veterinary Ophthalmology, 1:119123

Cassatella MA (1995) The production of cytokines by polymorphonuclear neutrophils. Immunology Today, 16:2126.

Cremonini DN, Ranzani JJT \& Marques MEA (2007) Transplante de membrana amniótica canina criopreservada para cicatrização de córnea com deficiência de células límbicas em coelhos. Arquivo Brasileiro de Medicina Veterinária e Zootecnia, 59:14621467.

Dua HS, Gomes JAP \& King AJ (2004) The amniotic membrane in ophthalmology. Survey of Ophthalmology, 49:51-77.

Goldim JR (1995) Pesquisa em saúde e direitos dos animais. Porto Alegre, HCPA, 28p.

Hao Y, Ma DH \& Hwang DG (2000) Identification of antiangiogenic and antiinflamatory proteins in human amniotic membrane. Cornea, 19:348-352.

Kern TJ (1990) Ulcerative keratitis. Veterinary Clinics of North American: Small Animal Practice, 20:643-666.

Kim JC \& Tseng SCG (1995) Transplantation of preserved human amniotic membrane for surface reconstruction in severely damaged rabbit corneas. Cornea, 145:473-484.

Kim JY, Choi YM \& Jeong SW (2009) Effect of bovine freezedried amniotic membrane (Amnisite-BA ${ }^{\mathrm{TM}}$ ) on uncomplicated canine corneal erosion. Veterinary Ophthalmology, 121:3642 .

Pontes KCS, Duarte TS, Machado DPD, Sepúlveda RV, Ramos DR \& Borges, APB (2010) Membrana amniótica bovina, preservada em glicerina, no tratamento de úlcera de córnea em um cão e de sequestro corneal em dois felinos - relato de casos. Revista Clínica Veterinária, 85:88-96.

Portnoy SL, Insler MS \& Kaufman HE (1989) Surgical management of corneal ulceration and perfuration. Survey of Ophthalmology, 34:47-58.

Sampaio IBM (2002) Estatística aplicada à experimentação animal. Belo Horizonte, Fundação de Ensino e Pesquisa em Medicina Veterinária e Zootecnia. 265p.

Sampaio RL, Ranzani JJT \& Rodrigues JV (2006) Aspectos clínicos e imunológicos da ceratoplastia com membrana amniótica xenógena fresca e conservada em glicerina. Estudo experimental em coelhos. Arquivo Brasileiro de Medicina Veterinária e Zootecnia, 58:1077-1085.

Shimura S, Shimazaki J \& Ohashi Y (2001) Antiinflammatory effects of amniotic membrane transplantation in ocular surgace disorders. Cornea, 20(4):408-413.
Slatter D \& Dietrich U (2007) Córnea e esclera. In: Slatter D (Ed.) Manual de cirurgia de pequenos animais. $3^{\text {rd }}$ ed, São Paulo, Manole, p. 1368-1396.

Spencer WH (1996) Cornea. In: Spencer WH (Ed.) Ophthalmic Pathology. 4 ed, Philadelphia, W. B. Saunders, p. 157-133.

Trelford JD \& Trelford-Sauder M (1979) The amnion in surgery, past and present. American Journal of Obstetric and Ginecology, 134:833-845

Whitley RD, (1991) Canine cornea. In: Gelatt KN (Ed) Veterinary ophthalmology. $2^{\text {nd }}$ ed, Philadelphia, Lea \& Febiger. p.347-356.

Wilson SE, Mohan RR \& Mohan RR (2001) The corneal wound healing response: cytokine-mediated interation of the epithelium, stroma, and inflammatory cells. Progress of Retinal Eye and Research, 205:625-637.

Rev. Ceres, Viçosa, v. 59, n.3, p. 313-320, mai/jun, 2012 